\title{
Surveying awareness of hand hygiene guidelines in the Sanin region of Japan
}

\author{
T Horii $^{1 *}$, Y Yoshida ${ }^{2}$, K Komatsu $^{2}$ \\ From International Conference on Prevention \& Infection Control (ICPIC 2011) \\ Geneva, Switzerland. 29 June - 2 July 2011
}

\section{Introduction / objectives}

Given the history of the 2002 CDC guidelines usage in Japan, we surveyed the awareness and adoption of WHO Guideline on Hand Hygiene in Health Care published in 2009, particularly the Five Moments of Hand Hygiene tool by healthcare workers (HCWs) in Japan.

\section{Methods}

A questionnaire survey was conducted on $64 \mathrm{HCWs}$ at the Tottori Prefecture Healthcare Associated Infection Control Seminar held on November, 2010.

\section{Results}

The rates for awareness on the WHO and CDC hand hygiene guidelines were $26(41 \%)$ and 28 (44\%) of Â HCWs, respectively. 14 (22\%) of HCWs were able to explain the WHO Five Moments of Hand Hygiene tool when asked, and $13(20 \%)$ had seen the tool but could not explain its meaning. The subject HCWs had reported being introduced to the WHO guideline tools through publications, reviews in Japanese scholarly journals and in seminar presentations. The rest (58\%)had no prior knowledge of the tool. All the subjects had never read the WHO guideline in English or a Japanese translation. However, 6 (9\%) of the subjects had read the CDC guidelines. In addition, 43 (67\%) of HCWs were willing to read the $\mathrm{WHO}$ guideline if a Japanese translation were available. There were many reasons why the survey subjects had not read the WHO Guideline, but the foremost reason was the lack of a Japanese translation.

\section{Conclusion}

During this investigation, we found that the HCWs who were aware of the new WHO guideline identified it with

${ }^{1}$ Infection Control Division, Tottori University Hospital, Yonago, Japan Full list of author information is available at the end of the article the included tools such as the 5 Moments of Hand Hygiene illustration, suggesting the strong impression of visual aids for $\mathrm{HCW}$ workplace education. Our results showed that many Japanese HCWs were willing to consider the WHO guidelines if a Japanese translation were available, which is thought to be necessary in releasing a Japanese translation of high quality as soon as possible and fostering faster adoption throughout the country.

\section{Disclosure of interest}

None declared.

\section{Author details}

${ }^{1}$ Infection Control Division, Tottori University Hospital, Yonago, Japan. ${ }^{2}$ Saraya Co., Ltd., Osaka, Japan.

Published: 29 June 2011

doi:10.1186/1753-6561-5-S6-P115

Cite this article as: Horii et al:: Surveying awareness of hand hygiene guidelines in the Sanin region of Japan. BMC Proceedings 2011 5(Suppl 6):P115.

Submit your next manuscript to BioMed Central and take full advantage of:

- Convenient online submission

- Thorough peer review

- No space constraints or color figure charges

- Immediate publication on acceptance

- Inclusion in PubMed, CAS, Scopus and Google Scholar

- Research which is freely available for redistribution
C Biomed Central

(c) 2011 Horii et al; licensee BioMed Central Ltd. This is an open access article distributed under the terms of the Creative Commons Attribution License (http://creativecommons.org/licenses/by/2.0), which permits unrestricted use, distribution, and reproduction in any medium, provided the original work is properly cited. 